ES/ER/TM-62

\title{
Aerial Remote Sensing Surveys Progress Report: Helicopter Geophysical Survey of the Oak Ridge Reservation
}

\author{
W. E. Doll J. E. Nyquist \\ A. D. King D. T. Bell \\ J. S. Holladay V. F. Labson \\ L. Pellerin
}

Environmental Restoration Program

P.O. Box 2003

Oak Ridge, Tennessee 37831-7298

Date Issued-March 1993

Prepared by

Health and Safety Research Division

Oak Ridge National Laboratory

Prepared for

U.S. Department of Energy

Office of Environmental Restoration and Waste

Management

under budget and reporting code EX 20

MARTIN MARIETTA ENERGY SYSTEMS, INC.

managing the

Oak Ridge K-25 Site

Oak Ridge Y-12 Plant

Oak Ridge National Laboratory under contract DE-AC05-84OR21400
Paducah Gaseous Diffusion Plant Portsmouth Gaseous Diffusion Plant under contract DE-AC05-76OR00001

for the

U.S. DEPARTMENT OF ENERGY 


\section{Author Affiliations}

W. E. Doll and J. E. Nyquist are members of the Environmental Sciences Division, Oak Ridge National Laboratory, Martin Marietta Energy Systems, Inc. A. D. King is a member of the Health and Safety Division, Oak Ridge National Laboratory, Martin Marietta Energy Systems, Inc. D. T. Bell is a member of the Program Integration and Administration Division (Environmental Restoration and Waste Management Organization), Martin Marietta Energy Systems, Inc. J. S. Holladay is a member of Geonics Aerodat, Ltd., Mississuaga, Ontario, Canada. V. F. Labson and L. Pellerin are members of the U.S. Geological Survey, Denver, Colorado.

\section{DISCLAIMER}

This report was prepared as an account of work sponsored by an agency of the United States Government. Neither the United States Government nor any agency thereof, nor any of their employees, makes any warranty, express or implied, or assumes any legal liability or responsibility for the accuracy, completeness, or usefulness of any information, apparatus, product, or process disclosed, or represents that its use would not infringe privately owned rights. Reference herein to any specific commercial product, process, or service by trade name, trademark, manufacturer, or otherwise does not necessarily constitute or imply its endorsement, recommendation, or favoring by the United States Government or any agency thereof. The views and opinions of authors expressed herein do not necessarily state or reflect those of the United States Government or any agency thereof. 


\section{CONTENTS}

EXECUTTVE SUMMARY $\ldots \ldots \ldots \ldots \ldots \ldots \ldots \ldots \ldots \ldots \ldots \ldots \ldots$ iv

1. INTRODUCTION $\ldots \ldots \ldots \ldots \ldots \ldots \ldots \ldots \ldots \ldots \ldots \ldots \ldots \ldots \ldots \ldots \ldots$

2. SITE DESCRIPTION $\ldots \ldots \ldots \ldots \ldots \ldots \ldots \ldots \ldots \ldots \ldots \ldots \ldots \ldots \ldots \ldots$

3. DATA ACQUISITION $\ldots \ldots \ldots \ldots \ldots \ldots \ldots \ldots \ldots \ldots \ldots \ldots \ldots \ldots \ldots \ldots$

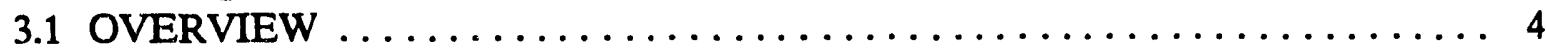

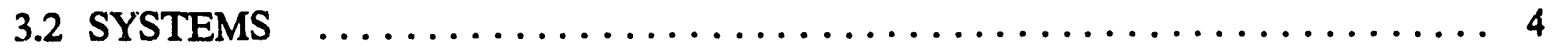

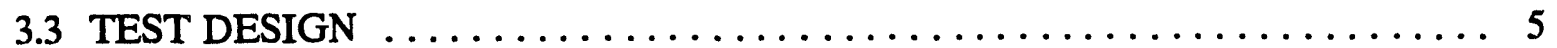

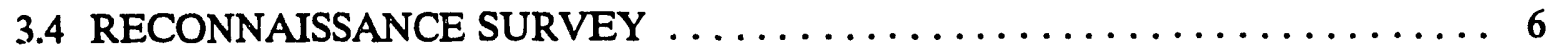

3.5 HIGH-RESOLUTION SURVEY $\ldots \ldots \ldots \ldots \ldots \ldots \ldots \ldots \ldots \ldots \ldots \ldots$

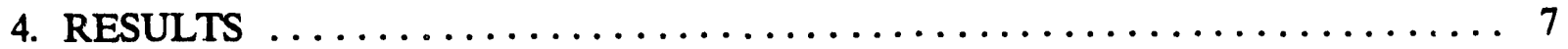

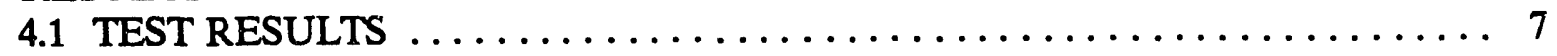

4.2 PRELIMINARY RESULTS OF THE RECONNAISSANCE SURVEY $\ldots \ldots 11$

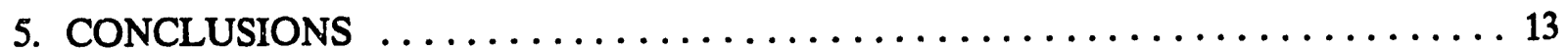

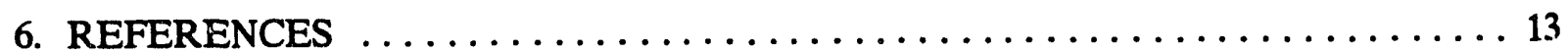




\section{EXECUTIVE SUMMARY}

The 35,252 acre Department of Energy Oak Ridge Reservation (ORR) in the western portion of the Appalachian Valley and Ridge Province in Tennessee, has been a nuclear production and development facility for $\mathbf{5 0}$ years. Contaminants in the many waste sites on the ORR include a wide variety of radioactive isotopes as well as many organic and inorganic compounds. The locations, geometry, and contents of many of these waste sites are reasonably well known, while others are poorly known or unknown. To better characterize the reasonably well known sites and search for additional potentially environmentally hazardous sites, a two-phase aerial survey of the ORR was developed. Phase I began in March 1992 and consisted of aerial radiation, multispectral scanner, and photographic (natural color and color infrared) surveys. Phase II began in November 1992 and is described in this report. Phase II consisted of helicopter electromagnetic (HEM), magnetic, and gamma radiation surveys. Targets of the survey included both man-made (drums, trench boundaries, burn pits, well heads) and geologic (fractures, faults, karst features, geologic contacts) features.

The Phase II survey has three components: testing, reconnaissance, and high-resolution data acquisition. To date, the testing and reconnaissance data acquisition have been completed, and some of the data have been processed. They indicate that: (1) magnetic and HEM data are complementary and do not always highlight the same anomaly; (2) under favorable circumstances, helicopter magnetometer systems are capable of detecting groups of four or more 55-gal drums at detector altitudes of $15 \mathrm{~m}$ or less; (3) HEM data provide data that compare favorably with surface data collected over burial trenches, (4) well casings may be related to magnetic monopole anomalies, as would be expected; and (5) changes in HEM and magnetic anomaly character are related to lithologic changes and may be used to track contacts between known outcrops. 


\section{INTRODUCTION}

Electromagnetic (EM) and magnetic geophysical methods have been an important component in the studies of environmental problems at the nation's nuclear facilities. Waste disposal landfills, disposal lagoons, injection wells, and leaking tanks and pipelines are some of the principal sources of pollutants entering groundwater supplies or adversely affecting the environment. In some studies, the objective may be to detect the pollutants directly and map the site, locating both hazardous constituents contained and leaking from the site. in other studies the primary objective may be to define the hydrologic conditions that govern migration of pollutants through and away from the site. The large size of the nuclear facilities and the need to assess the facilities make traditional ground-surveying methods ineffective in regional environmental restoration surveys. The presence of high levels of contamination or heavy brush may cause ground-based data acquisition to be particularly hazardous or difficult. Airborne methods can be used to minimize hazards associated with exposure to contaminants, and difficult surface conditions can be avoided entirely. Furthermore, the ability of ground EM and magnetic techniques to characterize the subsurface can be efficiently extended by using airborne geophysical tools borrowed from the mineral exploration industry. The transfer of this technology is straightforward, and airborne surveys have been applied in several recent hydrologic and environmental studies (Smith et al. 1992, Bourgeois et al. 1992, Frischknecht et al. 1991). For most applications, helicopter electromagnetic (HEM) and magnetic methods are preferred over those using fixed-wing aircraft because higher-resolution data may be obtained.

Disposal site records often are missing or inadequate. Reconnaissance airborne geophysical surveys can provide the initial step in locating undocumented disposal areas. The electrical resistivity structure and magnetic signature of a disposal site is generally quite different from that of the surrounding, undisturbed media. This is partly because of the addition of waste material in which the resistivity and magnetization may differ greatly from that of natural earth materials. Also, the resistivity of earth materials is altered by the process of excavation and refilling. Thus, HEM and magnetics can be very useful in mapping trenches, pits, and similar features. These disposal areas cause frequent concern because of the migration of pollutants away from the site. If a leachate plume originating from a disposal site has a high content of dissolved ionic constituents (e.g., salts, acids), the conductivity will be greater than that of the surrounding uncontaminated groundwater, and the plume can be detected and mapped. Brines or other pollutants driven to the surface by injection wells or natural brine layers that define the bottom of the potable aquifer can also be detected with EM mapping methods.

Mapping lithologic and structural features that influence the flow of groundwater through and away from disposal sites or other sources of pollutants is an important indirect use of EM methods. For example, coarse-grained, unconsolidated materials that may serve as aquifers can have relatively high resistivities unless their pores are filled with brine or water containing other conductive constituents. Subsurface voids and solution channels in carbonate terranes can be significant groundwater flow paths and are detectable when filled with conductive fluids or clay. Clay layers, which often form aquicludes in unconsolidated deposits, give rise to low resistivity EM anomalies. The resistivity and magnetization of crystalline bedrock is 
generally high, and by comparison, the resistivity and magnetization of sedimentary bedrock is often low. Fracture zones that may be very important in the flow of groundwater through consolidated media can often be detected as resistivity lows by EM profiling. A combination of EM resistivity mapping and sounding methods can be useful in mapping the water table in coarse unconsolidated materials. In mining exploration, geophysical daia are often used to locate drill holes and minimize the number of holes drilled. In environmental exploration, however, accurate drill-hole location is more than an economic issue. An improperly located hole can create a hazard or spread a contaminant. Additionally, airborne geophysical maps are useful in locating areas in need of detailed ground follow-up.

\section{SITE DESCRIPTION}

The Oak Ridge Reservation (ORR), located near Oak Ridge, Tennessee, comprises 35,252 acres in the Appalachian Valley and Ridge province (Fig. 1), located in one of the classic foreland fold-thrust belts. About $20 \%$ of the ORR consists of dense cultural features, including buildings and plants, roads, or high concentrations of power lines where aerial surveying is of no benefit. Most of the undisturbed land on the ORR is covered with a mix of coniferous and deciduous trees up to $40-80 \mathrm{ft}$. Approximately $15 \%$ of the reservation is composed of waste burial sites, sensitive environmental areas, and areas of high radioactivity, some of which have been cleared of trees. The reservation is bounded to the east, west, and south by the Clinch River and to the north by East Fork Ridge and the city of Oak Ridge (Fig. 1).

Studies of the ORR's structural geology (Hatcher et al. 1992) show a sequence of sedimentary units dipping to the southeast at roughly $45^{\circ}$, interrupted by two large thrust faults-Copper Creek and White Oak Mountain. The sedimentary sequence consists of Cambrian- to Mississippian-age shales and carbonates with a total thickness of $3000 \mathrm{~m}$. Differential weathering of these interstratified units produced the area's characteristic valley and ridge topography.

The complicated nature of the local geology makes characterization of the ORR hydrogeology difficult. The current conceptual model (Solomon et al. 1992) holds that the carbonate units, the Knox Group, and the Maynardville Limestone can be classified as aquifers, with the remaining geologic units acting as aquitards. Neither the shales nor the carbonates are represented as simple porous media. The carbonate units contain solution features (e.g., conduits) that may be significant pathways for groundwater flow and, possibly, contaminant migration. In the shales, groundwater flow appears to be dominated by a network of interconnected fractures, although matrix diffusion processes control the long-term movement of contaminants.

Numerous slug and packer tests on the ORR show that permeability decreases rapidly with depth (Solomon et al. 1992). It is estimated that approximately $98 \%$ of the total groundwater flow occurs within the top $30 \mathrm{~m}$., with $90 \%$ or more occurring in the storm-flow zone-a thin layer, roughly corresponding to the root zone. This zone is normally unsaturated but saturates during rainy periods, and its relatively high hydraulic conductivity accounts for its importance in shallow groundwater flow. 


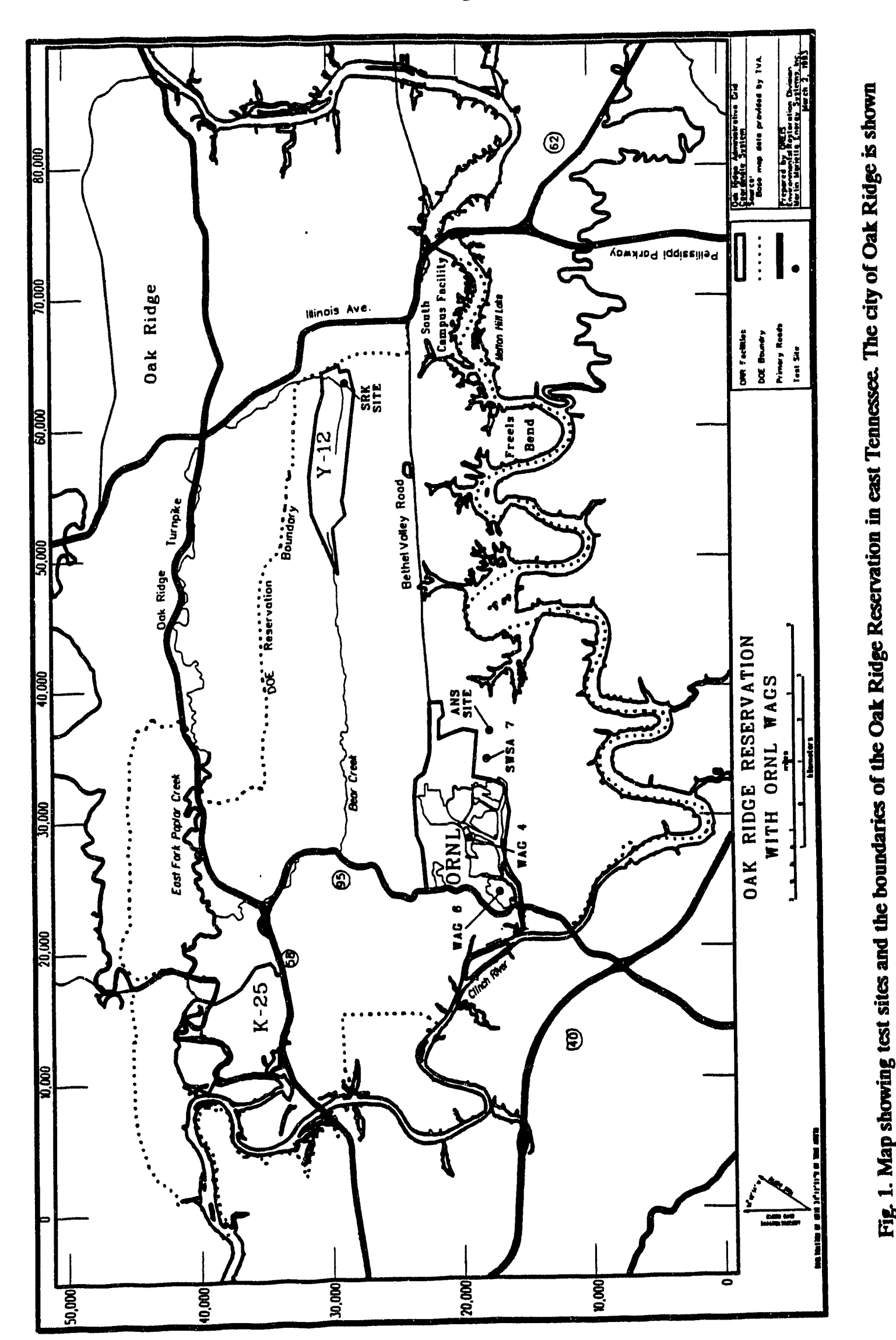


The ORR airborne geophysical data can be used to assist hydrogeologists in mapping source areas and contaminant migration pathways or to assist site managers desiring better information on known and unknown waste site configurations and locations. Relevant geophysical targets include: (1) karst cavities and conduits, (2) major faults and fracture systems, (3) soil cover type and thickness, and (4) buried steel drums, silos, pipelines, trenches, and other man-made hazardous materials. In some areas, numerous buildings, roads, fences, and utilities can interfere with the magnetic and EM responses, but the ORR encompasses large tracts of undeveloped land. The regional airborne geophysical data display large-scale geologic features, reveal any large, undocumented waste areas, and suggest areas for follow-up ground-based geophysical surveys. Our current research focuses on extracting additional information from the aerial data and on overcoming ti:e problem posed by known sources of cultural interference.

\section{DATA ACQUISITION}

\subsection{OVERVIEW}

Because airborne geophysical surveys for detection and characterization of environmental targets are not routine, and because site conditions and instrumentation will differ with each survey, it is necessary to conduct a series of tests (beyond those routinely performed to ensure that the acquisition system is functioning properly) at the beginning of the survey to optimize the system and determine its sensitivity to the desired targets. Extensive testing of the data acquisition systems, which are described in Sect. 3.3, was conducted at sites within the ORR during November and December 1992. Preliminary results from these tests were used to select parameters for the reconnaissance survey, which was conducted in December 1992 and January 1993 . Once the test data and reconnaissance data have been fully processed and maps have been analyzed, sites for high resolution aerial surveys will be selected. It is anticipated that these surveys will be flown during the spring or autumn of 1993.

\section{SYSTEMS}

Two integrated HEM/Magnetic Gradiometer/VLF-EM/Radiometric systems were mobilized for the test phase: System A, designed for reconnaissance surveying, was flown at a nominal survey altitude of $30 \mathrm{~m}$ above ground level (AGL), while System B was designed to permit surveying at altitudes as low as $5 \mathrm{~m}$ AGL for detailed location and identification of targets. An Aerospatiale SA315B Lama leased from Rocky Mountain Helicopters was used to perform all airborne survey work.

System A included a Geonex Aerodat six-frequency HEM system operating at frequencies of $849,936,4189,4476,32,490$ and $36,069 \mathrm{~Hz}$. These frequencies were arranged in three horizontal coplanar/vertical coaxial pairs to facilitate discrimination of extended and localized conductive targets. The EM coil separations averaged $6.5 \mathrm{~m}$, while the tow cable length was $50 \mathrm{~m}$. A laser profilometer was mounted in a cylindrical house or bird; the bird altitude was measured using pendulum potentiometers. The vertical magnetic gradiometer included two cesium high-scnsitivity magnetometer sensors separated by $3 \mathrm{~m}$; the gradiometer was suspended $30 \mathrm{~m}$ below the helicopter along the main tow cable. The VLF (very low 
frequency) -EM sensors were also located within the gradiometer bird. The Global Positioning System (GPS) antenna was located on a small platform attached to the tow cable $10 \mathrm{~m}$ above the gradiometer bird. Finally, the gamma-ray spectrometer was an Exploranium system using a $16.8 \mathrm{~L}$ (1024 in. ${ }^{3}$ ) downward-looking crystal pack, a $4.21 \mathrm{~L}$ (256 in. ${ }^{3}$ ) upward-looking crystal, and a GR860 radiometric console. The crystal pack for this system was mounted on the portside cargo basket of the Lama.

The "high resolution" system (System B) used a small HEM/magnetic gradiometer bird developed for this survey by the contractor. This system included a wideband transmitter with its main power output at $4000,12,000,20,000,28,000$ and $34,000 \mathrm{~Hz}$ and a transmitterreceiver separation of $3.76 \mathrm{~m}$. The bird includes a laser profilometer and altitude sensors and is flown on a $30 \mathrm{~m}$ tow cable. Vertical magnetic gradient measurements were made using a pair of cesium high-sensitivity magnetometer sensors, separated by $1 \mathrm{~m}$, located in the "stinger" structure at the rear of the bird. The GPS antenna was mounted on top of the EM bird, while the receiver console remained in the helicopter. No VLF-EM was measured with this system. The radiometric package was identical to that described for the reconnaissance system.

A real-time differential GPS navigation system utilizing P-Code signals was used to position the system. The receiver antenna was mounted along the tow cable for System $A$ and on the bird for System B. Nominal accuracy for the GPS system is reported at "decimeter level," and accuracies approaching this level were observed in practice. Editing of the flight path was found to be unnecessary for the survey data presented in this summary.

\subsection{TEST DESIGN}

Preliminary tests were designed to investigate sensitivity to known targets, to compare airborne data with surface measurements, and to determine the extent of data degradation caused by topography, tree cover, and power lines. These tests were conducted at five sites on the reservation as shown in Fig. 1: Waste Area Group (WAG) 4, WAG 6, Solid Waste Storage Area (SWSA) 7, the Preferred Advanced Neutron Source Site (ANS site), and the Scarboro Road Karst (SRK) site.

WAG 4 was chosen because densely spaced surface measurements using an EM-31 coupled to the Ultrasonic Ranging and Detection System (USRADS) had effectively delineated burial trench boundaries in the eastern portion of the site (Nyquist and Blair 1991). This provides a valuable comparison between HEM and simple surface conductivity measurements (Nyquist and Doll 1993). The western portion of WAG 4 has not yet been surveyed with surface instruments and is therefore of particular interest.

WAG 6 is a disposal site that is currently active, where several technologies have been used to place wastes in trenches and buried silos. A large power line crosses the site, providing an opportunity to determine the ability of the system to detect disposal sites in the presence of severe noise.

SWSA 7 is an undisturbed site that will become a waste site in the future. A sloping clearing within SWSA 7 was chosen as a site for testing the sensitivity of the helicopter system

to groups of 55-gal steel drums. Groups of one, two, four, and eight drums were arranged in a 100-ft square at the center of the clearing. Wikitin each group, the drums were tightly 
clustered but were not bound in a way that would ensure electrical contact. The location of the drum groups was subsequently measured with the same GPS system that was used in flight.

The ANS site, like SWSA 7, is undisturbed and has irregular topography. However, the ANS site has not been cleared of trees. Data were collected at the ANS site in order to determine the effect of irregular topography at a tree covered site where the laser altimeter might detect tree tops rather than true surface elevation. Because data were collected where deciduous trees are dominant and after the leaves had fallen, the site conditions were likely to represent the best case. Four groups of 55-gal drums were deployed at the site-two on a linear ridge and two in a parallel linear topographic low, $\sim 150 \mathrm{ft}$ away and $25 \mathrm{ft}$ lower. Drum groups consisted of two and five drums on the ridge and in the low area.

The SRK feature was discovered in September 1991, when a 40-ft void at a 60-ft depth was encountered while drilling a monitoring well. The void is filled with a mixture of clay-rich mud and water. Subsequent geophysical measurements indicate a 150-microgal gravity anomaly centered near the drilling site. It has become a test site for geophysical detection of karst features on the ORR. Testing of the aerial system at this site was part of the effort to evaluate geophysical karst detection methods.

Once completed, the test data set will consist of a series of maps from different elevations ranging in altitude from 50 to $100 \mathrm{AGL}$ (the minimum elevation depending on tree height) and flight line spacings ranging from 50 to $150 \mathrm{ft}$. Data collected with both crossstrike and strike-parallel flight direction will be available at the WAG 4 and WAG 6 sites. At SWSA 7 and the ANS site, data were collected with drums present and removed to separate their signature from the background. The tests were repeated with both of the Aerodat systems that have been described in Sect. 3. A hovering technique was evaluated at the SWSA 7 and Scarboro Road sites to achieve the lowest possible altitude and highest resolution.

\subsection{RECONNAISSANCE SURVEY}

Data were acquired over the entire ORR using a nominal flight line spacing of $150 \mathrm{ft}$ at an altitude of $100 \mathrm{ft}$, using System $A$ (Sect. 3). By conventional HEM standards, these parameters would define a high-resolution survey. For our purposes, the reconnaissance survey was designed for detection of large environmental targets and for characterizing those geologic features that influence contaminant migration (e.g., faults and fractures) or the features that must be taken into consideration when evaluating higher-resolution data, such as that over the waste sites. Previous attempts to interpret high-resolution environmental data without the requisite reconnaissance data have led to additional ambiguities and uncertainties in the processing and interpretation stages. 


\subsection{HIGH-RESOLUTION SURVEY}

After analyzing the test results and magnetic, magnetic gradient, conductivity, and radiometric maps from the reconnaissance flights, sites for high-resolution data acquisition will be selected. These sites will likely focus on waste sites that are cleared of trees and those where the boundaries of trenches and other targets are not well known. Other targets may include sites where surface access is severely hampered or where the extrapolation of known features, such as karst features, to adjacent areas is desired.

\section{RESULTS}

The following figures and the discussion below are preliminary and subject to change. Final maps have not been generated or reviewed by a contractor, and interpretation and analysis of the preliminary data are only in the earliest stages. Several types of postprocessing are planned, and it is anticipated that these will significantly enhance the interpretation of the data.

\subsection{TEST RESULTS}

A vertical magnetic gradient map collected with System B over the WAG 6 test site is shown in Fig. 2. This and all of the maps in this report were plotted in Oak Ridge National Laboratory administrative grid coordinates in units of feet, with grid north oriented $34.2^{\circ}$ west of true north. The east-west oriented flight lines are superimposed as fine solid lines on the map, and the WAG boundary is represented by the wide solid line. The western portion of WAG 6 was not included in the test site. Contours are at irregular intervals, which were selected to highlight features on the map. The range of values corresponding to each contour interval is given in the legend in units of nanotesla per meter. Known features causing the anomalies are shown in the detailed map of WAG 6 in Fig. 3. The largest anomalies are related to the high- and low-activity silos and buildings. A large anomaly south of the "High Range Wells" label (Fig. 3) is caused by a large pile of scrap piping at the surface. As expected, disposal trenches containing low- and high-activity materials (Caps 1, 2, 4, 7, and Control Trenches) also have very strong signatures. Smaller anomalies tend to be associated with biological trenches (Caps 5 and 8). The smallest disposal site anomalies are associated with asbestos trenches (Cap 6) and high-activity auger holes (Cap 3). The areas outside of the WAG boundary are largely undisturbed and have only small anomalies that might be associated with roads or natural geologic features.

Figure 4 is conductivity map (following Holladay 1980) produced from 12-kHz horizontal coplanar EM test data. Units of the grey scale are in millisiemens per meter. The location of a high-voltage power line that interfered with the data is shown by the dot-dashed line. Flight lines are indicated by the fine solid lines, and the WAG boundary is represented by the wide

solid line. Within the WAG, there are no strong relationships between conductivity anomalies and disposal areas, perhaps because the entire area is disturbed. There appears to be a relationship between high conductivities and the streams and drainages within the WAG, although this relationship does not carry to the stream that flanks the eastern side of 


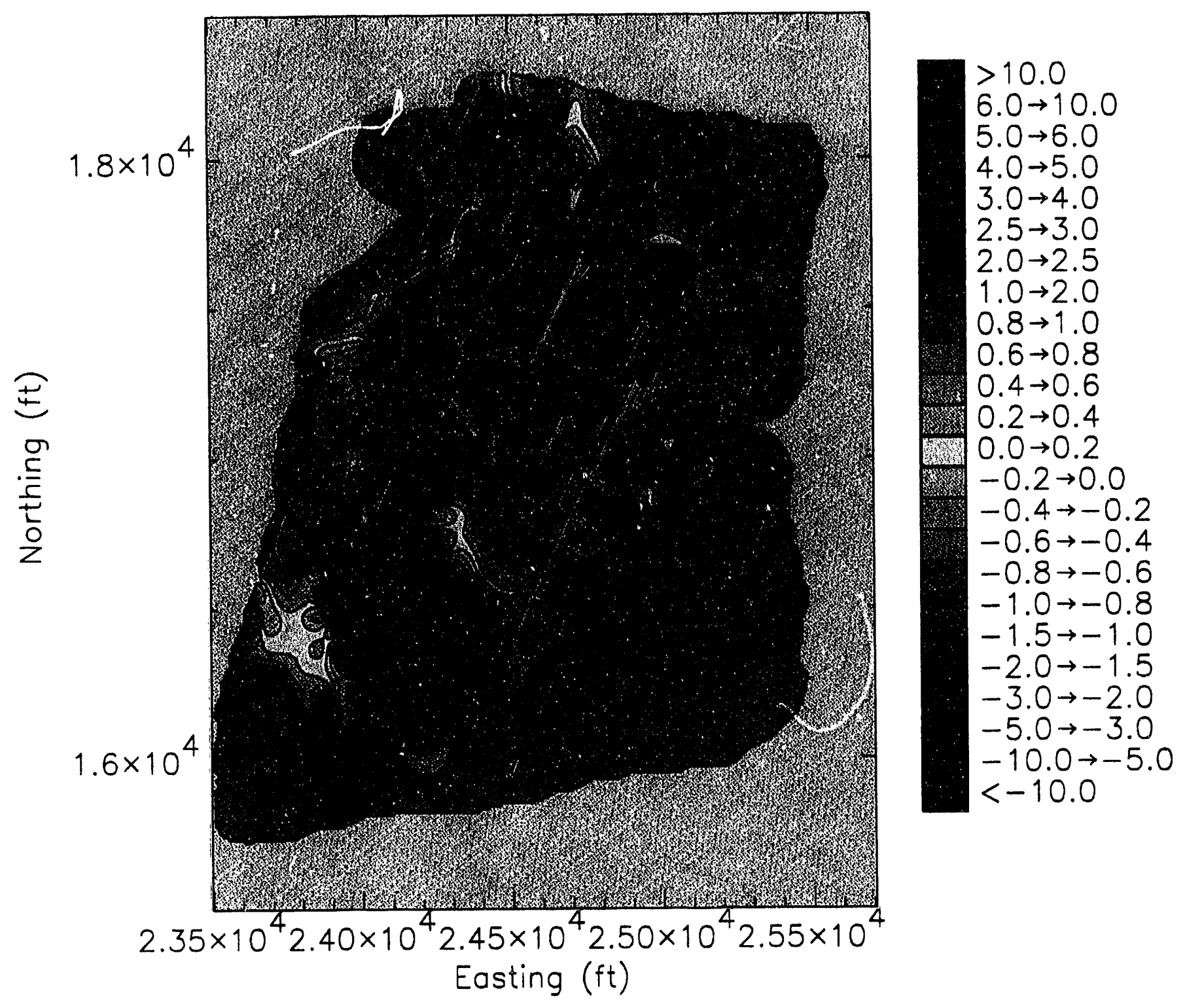

Fig. 2. Vertical magnetic gradient map of the WAG 6 waste site for east-west flight lines (superimposed). Contour interval is not constant but is indicated in the legend in units of nanotesla per meter. The outline of WAG 6 is indicated with a heavy black line. Anomalies may be correlated with features in Fig. 3. 


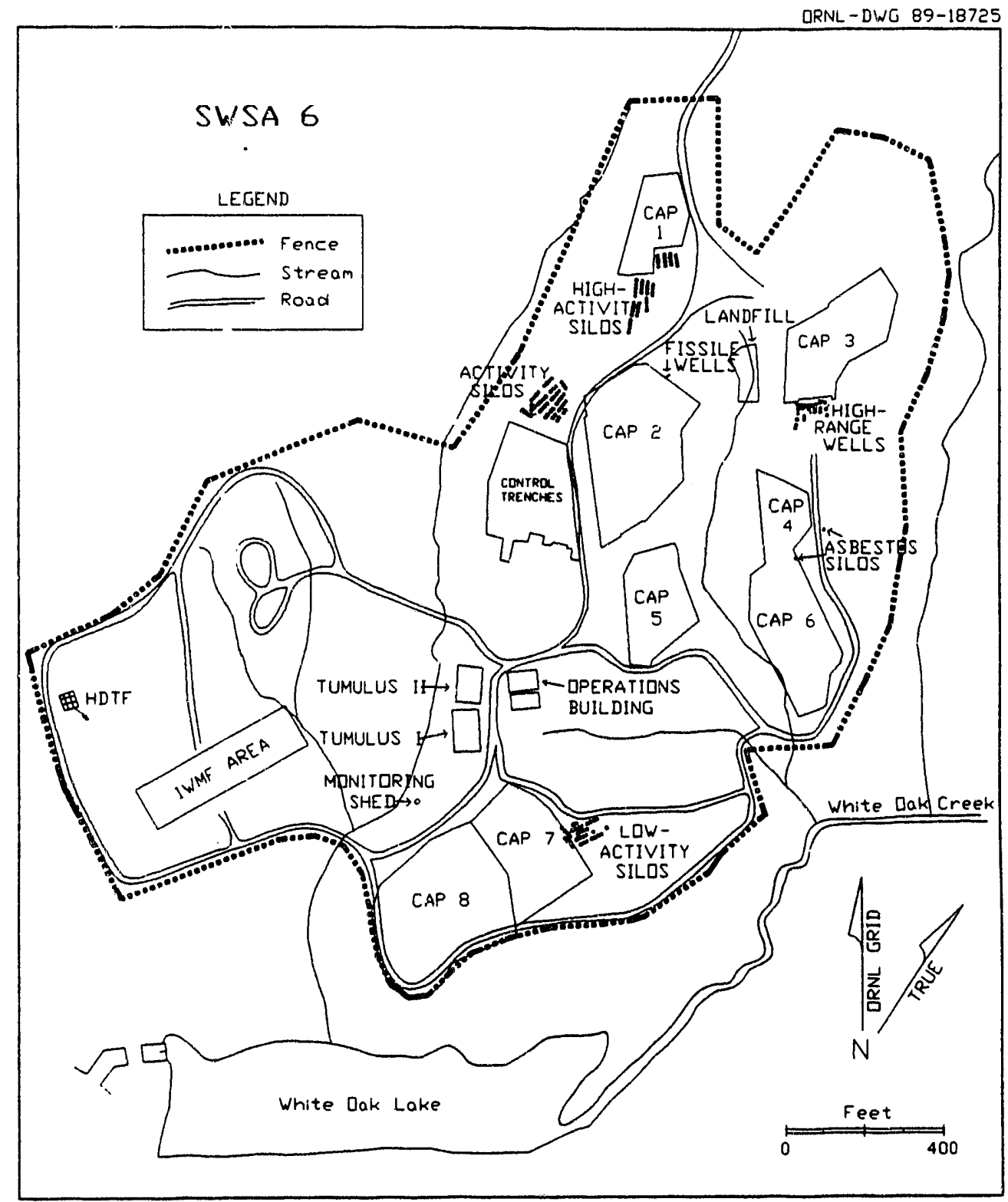

Fig 3. Map showing waste sites in WAG 6. The perimeter of WAG 6 is shown by the heavydashed lines. Roads, buildings, and streams are also indicated. Wastes are confined to the capped areas and control trenches. Where possible, the locations of trenches within the capped areas are indicated. The text discusses relationships between this map and the anomalies in Fig. 2 and 4. 


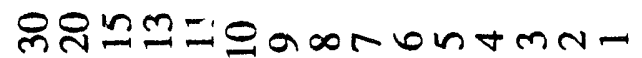

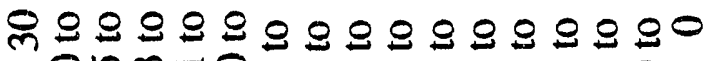

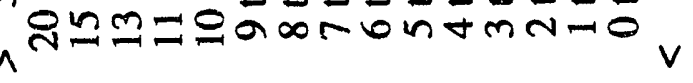

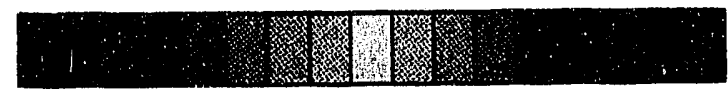

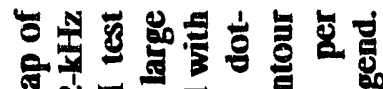

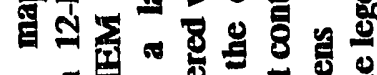

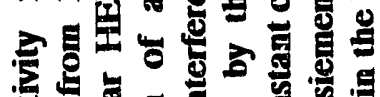

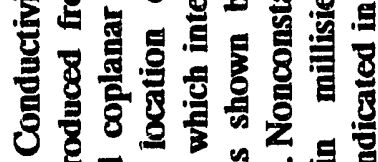
$8 \% 83$ क 2.

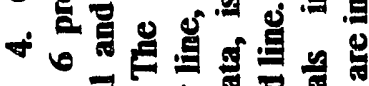

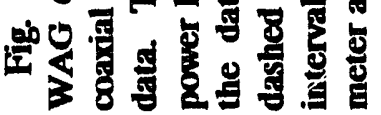

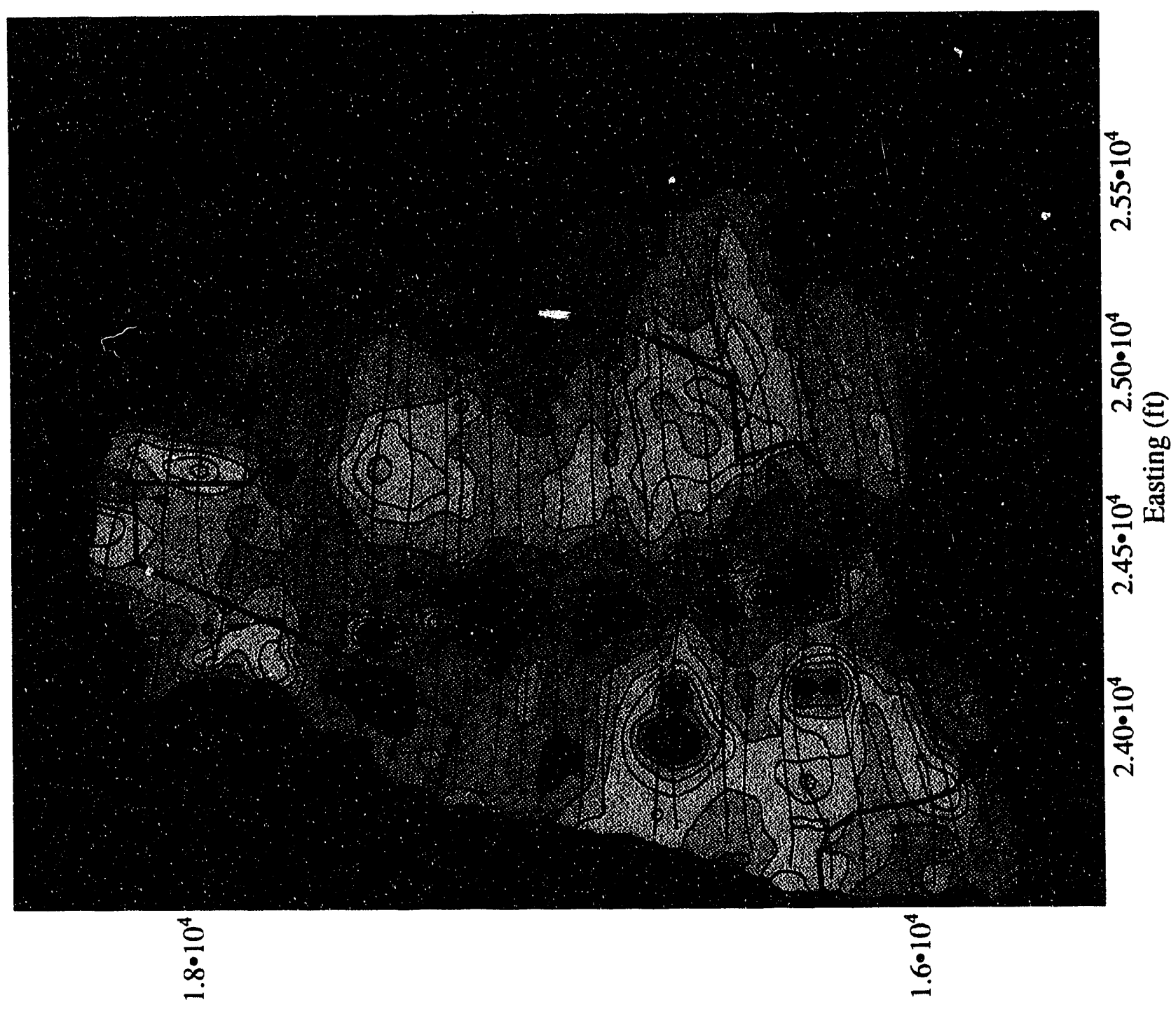

(1ร) ชิบ!บนION 
the WAG. This relationship may be a deception because the power line is located between the two primary drainages. In general, capped trench areas tend to be marked by conductivity highs, although there are exceptions. It is expected that further processing will produce useful results from these data.

The 12-kHz horizontal coplanar EM data collected over the WAG 4 site (not shown) were more successful in defining trench boundaries and are in agreement with the surface data that were previously collected over a portion of WAG 4 with a Geonics EM-31 coupled to the USRADS data acquisition and positioning system (Nyquist and Blair 1991). The aerial data show the continuation of features observed in the surface data to the rest of SWSA 4 and highlight trench boundaries and other known features in the burial ground (Nyquist and Doll 1993).

Figure 5 shows magnetic gradient profile maps from north-south and east-west flights across the SWSA 7 drum test site. Locations of the drum groups are indicated by " $\mathrm{X}$ " symbols, which are labeled according to the number of drums in the group. The data indicate that the magnetic gradiometer in System B was capable of detecting groups of four or more drums with sensor elevations of $15 \mathrm{~m}$ and lower when the bird passed almost directly over the drums. The east-west flights suggest that in some cases it might be possible to detect two-drum groups in this type of geology. The cause of the large signals $\sim 100 \mathrm{ft}$ west of the single drum test flight (line 71022) is unknown, though it is likely to be a result of vehicles passing by on a nearby road or perhaps a cased well. No obvious sources for the anomaly were observed in the field or in the flight video record, and no errors are known to exist in the raw data. The ability to detect drum groups, which are offset from the flight line, has not been fully investigated. Anomalies related to the drums can also be seen in the total field magnetometer data. The HEM sensors were not sensitive to drum groups at the altitudes tested.

Magnetic profiles acquired with System A at the Scarboro Road test site passed over several cased wells having depths on the order of 50 to $100 \mathrm{ft}$. The positions of wells have not yet been superimposed on the total field magnetic data, but there appears to be a strong magnetic monopole signal associated with many or all of the wells. EM data acquired with System B at altitudes of $15 \mathrm{~m}$ show significant conductive anomalies that might be related to the known karst feature. Confirmation of this relationship will require that the data collection be repeated, because postprocessing of GPS navigation data failed to recover true flight path. Surface data are being acquired to compare with the HEM data.

\subsection{PREILIMINARY RESULTS OF THE RECONNAISSANCE SURVEY}

To date, preliminary magnetic gradient and total magnetic field contour maps and EM profile maps for $4-\mathrm{kHz}$ coaxial and coplanar coils have been generated for a small segment of the reconnaissance data. Data quality are adequate to permit contouring at a one-gamma interval in the magnetic maps and $0.5 \mathrm{gamma} / \mathrm{m}$ in the gradient maps. Preliminary apparent conductivity maps have been generated following one-dimensional inversion of profile data and show very strong correlations with mapped geologic contacts between shales and limestones. In some places, there are indications that modification of the mapped lithologic contacts may be in order. Comparisons of the magnetic and EM maps indicate that each is sensitive to a different type of anomaly, so that both data sets are valuable. There are 


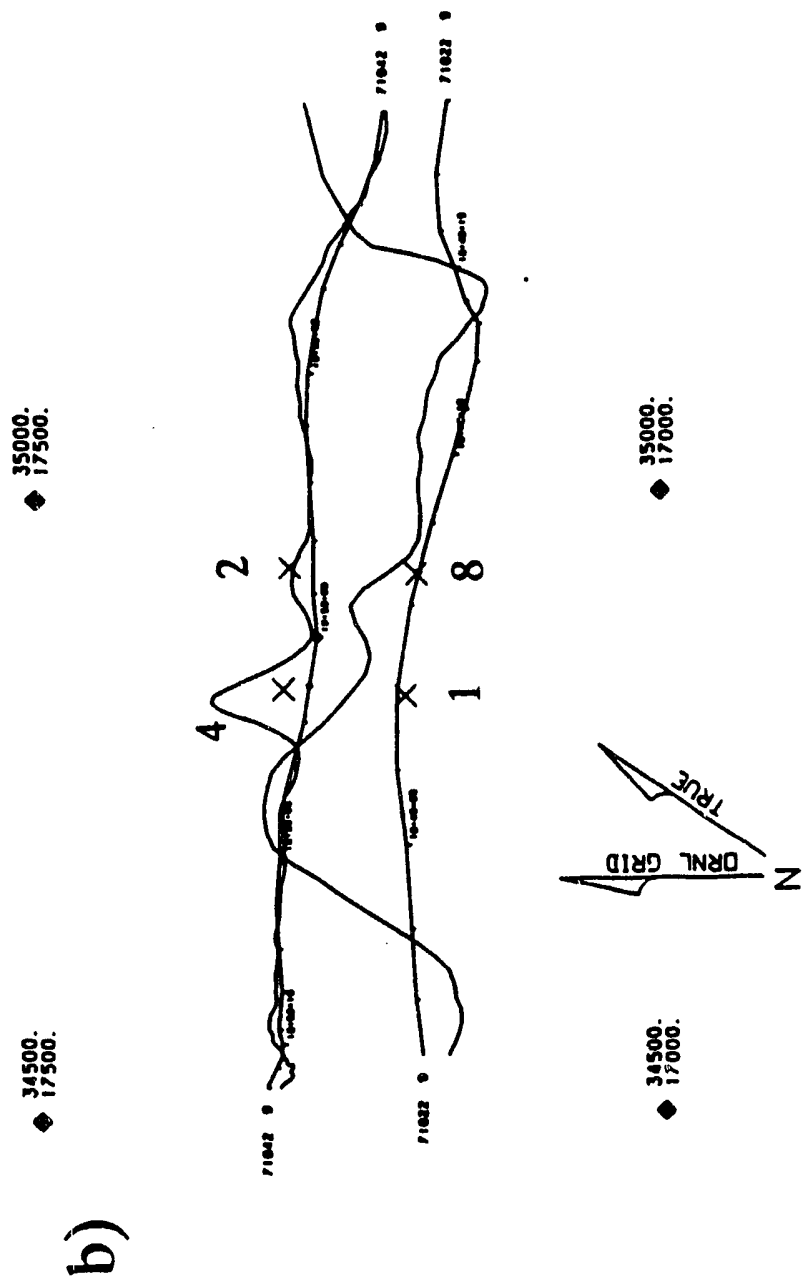

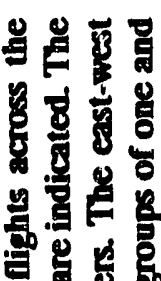

曾

담

预

อ.

- 물

豆豆

을

을

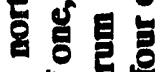

这훙

동

อ룽요

을 행옹

늘

룽을

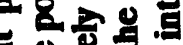

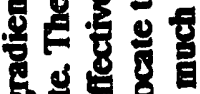

क

월

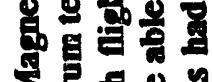

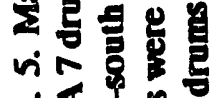
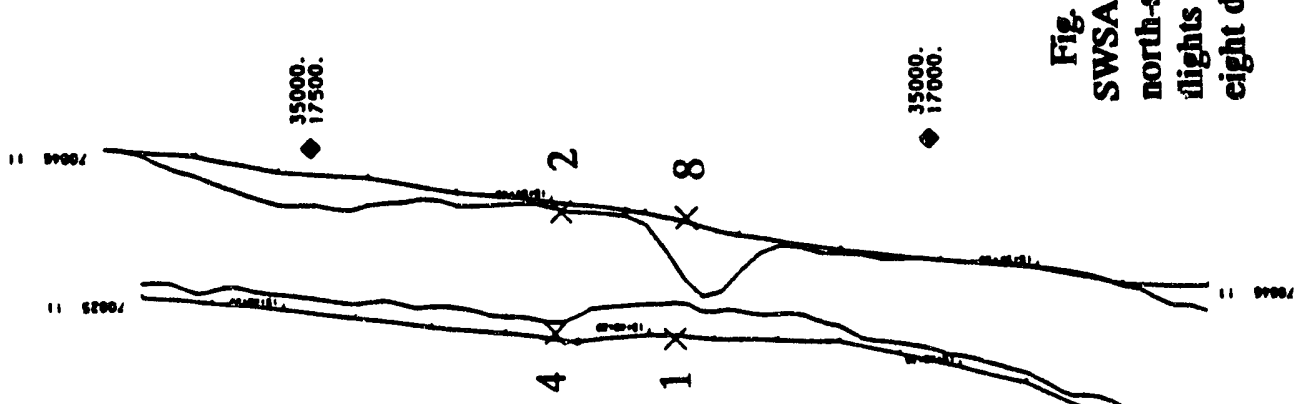

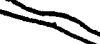

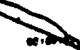

i

$\approx$

蜜

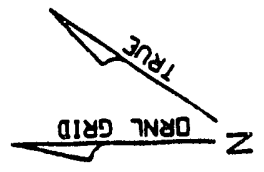

密嶉 
presently unexplained anomalies on both magnetic and EM maps which appear to be man-made and are presently unexplained.

\section{CONCLUSIONS}

Preliminary results of the ORR geophysical airborne surveys indicate that airborne magnetic and HEM methods are very useful reconnaissance tools when searching for unknown waste sites, characterizing geologic features that might control contaminant migration, and refining the positions of known waste site boundaries. Airborne methods are capable of detecting groups of four or more 55-gal drums from sensor altitudes of $15 \mathrm{~m}$ or less, detecting trench boundaries and large metal burial sites, locating lost well heads, and detecting many other "environmental" targets. The data are also valuable for mapping geologic contacts that might constrain contaminant migration. Many other important results are expected once these data are fully processed and analyzed.

\section{REFERENCES}

Bourgeois, B., Y. Gros, R. Andre Jehan, J. P. Vervialle, J. Gamey, and J. S. Holladay. 1992. Estimation of Thickness of Weathered Granite by 1D Inversion of Airborne Frequency EM Data, European Association of Exploration Geophysicist Proceedings, Paris.

Doll, W. E., J. E. Nyquist, J. S. Holladay, V. F. Labson, and L. Pellerin. 1993. Preliminary Results of a Helicopter Electromagnetic and Magnetic Survey of the Oak Ridge Reservation, Tennessee for Environmental and Geologic Site Characterization. Symposium for the Application of Geophysics to Engineering and Environmental Problems, San Diego, April 1993 (submitted).

Frischknecht, F. C., V. F. Labson, B. R. Spies, and W. L. Anderson. 1991. "Profiling Methods Using Small Sources, " in Electromagnetic Methods in Applied Geophysics, 2 Applications, Soc. Expl. Geophy., Nabighian, Minn. (ed.), Tulsa, Okla., pp. 105-270.

Hatcher, R. D. Jr., P. J. Lemiski, R. B. Dreier, R. H. Ketelle, R. R. Lee, D. A. Leitzke, and W. M. McMaster, J. L. Foreman, and S. Y. Lee. 1992. Status Report on the Geology of the Oak Ridge Reservation, ORNL/TM-12074, Martin Marietta Energy Systems, Inc., Oak Ridge National Laboratory, Oak Ridge, Tenn., p. 244.

Holladay, J. S. 1980. "Interpretation of Electromagnetic Sounding Data for a Stratified Earth by Means of Nonlinear Regression," M.S. thesis, in Research in Applied Geophysics, vol. 16, University of Toronto.

Nyquist, J. E., and M. S. Blair. 1991. "A Geophysical Tracking and Data Logging System: Description and Case History," Geophysics, 56, 1114-1121. 
Nyquist, J. E. and W. E. Doll. 1993. Comparison of Surface and Aerial Geophysics for Characterizing a Hazardous Waste Site: A Case Study. Abstract. Sixty-Third Society of Exploration Geophysicists Annual Meeting, Washington D.C., September 1993 (submitted).

Smith, B. D., K. P. Sengpiel, J. Plesha, and R. J. Horton. 1992. "Airborne Electromagnetic Mapping of the Subsurface Brine, Brookhaven Oil Field, Mississippi," Soc. Expl. Geophy Expanded Abstracts with Biographies, pp. 340-343.

Solomon, D. K. G. K. Moore, L. E. Toran, R. B. Dreier, and W. M. McMaster. 1992. Status Report: A Hydrologic Framework for the Oak Ridge Reservation, ORNL/TM-12026, Martin Marietta Energy Systems, Inc., Oak Ridge National Laboratory, Oak Ridge, Tenn. 


\section{DISTRIBUTION}

1. D. T. Bell

2. K W. Cook

3. R. B. Cook

4. J. S. Colley

5. D. G. Cope

6. M. F. P. DeLozier

7-11. W. E. Doll

12. R. B. Dreir

13-17. R. C. Durfee

18. T. O. Early

19. J. T. Grumski

20. K. G. Kahl

21. B. L. Kimmel

22-31. A. D. King

32. R. J. Luxmoore

33-34. D. M. Matteo

35. C. W. McGinn

36-40. J. E. Nyquist

41-42. P. T. Owen

43. G. E. Rymer

44. T. D. Taylor

45. J. S. Watson

46. R. K. White

47. Central Research Library

48-52. ER Document Management Center

53. ORNL Laboratory Records

54. Office of Assistant Manager for Energy Research and Development, DOE Oak Ridge Field Office, P.O. Box 2001, Oak Ridge, TN 37831-8600

55-60. D. M. Carden, Department of Energy, Oak Ridge Field Office, EW-91358-59.

61-65. J. S. Holladay, Geonex Aerodat, Inc., 3883 Nashua Drive, Mississauga, Ontario, Canada, LAV1R3

66-71. V. F. Labson, United States Geological Survey, Branch of Geophysics, Denver Federal Center, Box 25046, MS964, Denver, Colorado 80225

72-73. Richard Nace, Branch Chief, Nonenrichment Facilities, Oak Ridge Program Division, Office of Eastern Area Programs, Office of Environmental Restoration, EM-423, Trevion 2, U.S. Department of Energy, Washington, DC 20585

74-78. L. Pellerin, United States Geological Survey, Branch of Geophysics, Denver Federal Center, Box 25046, MS964, Denver, Colorado 80225

79. S. P. Riddle, Chief Decontamination and Decommissioning Branch, Department of Energy, Oak Ridge Field Office, EW-913

80. D. W. Swindle, Radian Corporation, 120 S. Jefferson Circle, Oak Ridge, TN 37830

81-82. H. M. Thron, Chief, Enrichment Facilities, Oak Ridge Program Division, Office of Eastern Area Programs, Office of Environmental Restoration, EM-423, Trevion 2, U.S. Department of Energy, Washington, DC 20585

83-84. Office of Scientific and Technical Information, P.O. Box 62, Oak Ridge, TN 37831 

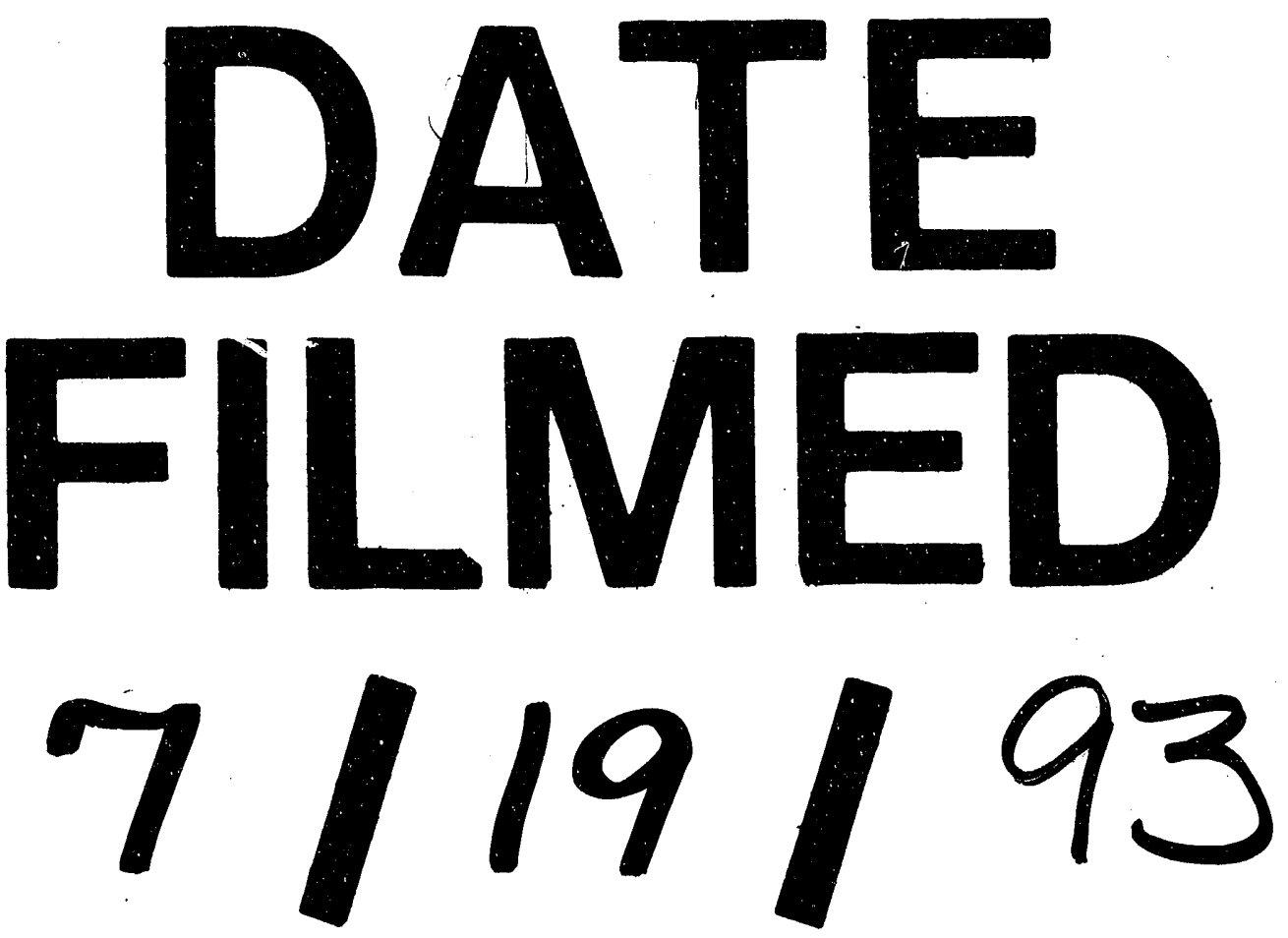
